\title{
Silencing Antibiotic Resistance with Antisense Oligonucleotides
}

\author{
Saumya Jani (D), Maria Soledad Ramirez (D) and Marcelo E. Tolmasky *(D) \\ Department of Biological Science and Center for Applied Biotechnology Studies, \\ California State University Fullerton, Fullerton, CA 92831, USA; saumyajani@csu.fullerton.edu (S.J.); \\ msramirez@fullerton.edu (M.S.R.) \\ * Correspondence: mtolmasky@fullerton.edu; Tel.: +1-657-278-5263
}

Citation: Jani, S.; Ramirez, M.S.;

Tolmasky, M.E. Silencing Antibiotic Resistance with Antisense

Oligonucleotides. Biomedicines 2021, 9,

416. https://doi.org/10.3390/

biomedicines 9040416

Academic Editor: Bernard Lebleu

Received: 1 March 2021

Accepted: 10 April 2021

Published: 12 April 2021

Publisher's Note: MDPI stays neutral with regard to jurisdictional claims in published maps and institutional affiliations.

Copyright: (c) 2021 by the authors. Licensee MDPI, Basel, Switzerland. This article is an open access article distributed under the terms and conditions of the Creative Commons Attribution (CC BY) license (https:/ / creativecommons.org/licenses/by/ $4.0 /)$.
Abstract: Antisense technologies consist of the utilization of oligonucleotides or oligonucleotide analogs to interfere with undesirable biological processes, commonly through inhibition of expression of selected genes. This field holds a lot of promise for the treatment of a very diverse group of diseases including viral and bacterial infections, genetic disorders, and cancer. To date, drugs approved for utilization in clinics or in clinical trials target diseases other than bacterial infections. Although several groups and companies are working on different strategies, the application of antisense technologies to prokaryotes still lags with respect to those that target other human diseases. In those cases where the focus is on bacterial pathogens, a subset of the research is dedicated to produce antisense compounds that silence or reduce expression of antibiotic resistance genes. Therefore, these compounds will be adjuvants administered with the antibiotic to which they reduce resistance levels. A varied group of oligonucleotide analogs like phosphorothioate or phosphorodiamidate morpholino residues, as well as peptide nucleic acids, locked nucleic acids and bridge nucleic acids, the latter two in gapmer configuration, have been utilized to reduce resistance levels. The major mechanisms of inhibition include eliciting cleavage of the target mRNA by the host's RNase H or RNase P, and steric hindrance. The different approaches targeting resistance to $\beta$-lactams include carbapenems, aminoglycosides, chloramphenicol, macrolides, and fluoroquinolones. The purpose of this short review is to summarize the attempts to develop antisense compounds that inhibit expression of resistance to antibiotics.

Keywords: antisense; antibiotic resistance; RNase P; RNase H; nucleotide analogs

\section{Introduction}

It has now been over 40 years since the pioneering research published by Zamenick and Stephenson, where the authors showed that the addition of a 13-mer oligonucleotide complementary to the repeated sequences located at the ends of the genome inhibited the replication of the Rous sarcoma virus in infected chicken embryo fibroblast cells [1]. These experiments were the origin of the antisense technologies, i.e., the utilization of oligonucleotides or oligonucleotide analogs to interfere with undesirable biological processes, commonly (but not exclusively), through inhibition of expression of selected genes. Since these pioneering experiments took place, a wide variety of strategies were designed to achieve therapeutic effects for the treatment of diverse diseases like viral and bacterial infections, genetic disorders, or cancer. Challenging problems such as toxicity, non-specific effects, or inability to penetrate the target were evident during the early years of antisense research, and progress was slow. However, steady progress was made, and in 1998, the Food and Drug Administration (FDA) approved fomivirsen (Vitravene ${ }^{\mathrm{TM}}$ ), an antisense drug indicated for cytomegalovirus retinitis treatment [2]. Following this breakthrough, many antisense drugs of a diverse chemical nature and that work through different mechanisms, including the utilization of siRNAs, were approved by the Food and Drug Administration (FDA) or European Medicines Agency (EMA) (see examples in Table 1, adapted with data from references [3-5]) and numerous others are at different stages of development such as miravirsen, a mixmer consisting of locked nucleic acid and phosphorothioate residues for the treatment of hepatitis C [3-12]. 
Table 1. Antisense medicines approved by the Food and Drug Administration (FDA) or European Medicines Agency (EMA).

\begin{tabular}{|c|c|c|c|c|c|c|c|}
\hline Drug & Chemistry & Route & Target & Indication & $\begin{array}{c}\text { Year } \\
\text { (FDA Approval) }\end{array}$ & $\begin{array}{c}\text { Year } \\
\text { (EMA Approval) }\end{array}$ & $\begin{array}{l}\text { Company, } \\
\text { Reference }\end{array}$ \\
\hline Fomivirsen (Vitravene ${ }^{\mathrm{TM}}$ ) & Phosphorothioate & Intravitreal & $\begin{array}{c}\text { Cytomegalovirus } \\
\text { mRNA }\end{array}$ & $\begin{array}{c}\text { Cytomegalovirus } \\
\text { infection }\end{array}$ & 1998 & - & Ionis Pharmaceuticals [2] \\
\hline Mipomersen (Kynamro $\left.{ }^{\mathrm{TM}}\right)$ & $\begin{array}{l}\text { 2'-O-Methoxyethyl, } \\
\text { Phosphorothioate, } \\
\text { 5-methyl cytosine }\end{array}$ & Subcutaneous & Apo-B-100 mRNA & $\begin{array}{l}\text { Homozygous familial } \\
\text { hypercholesterolemia }\end{array}$ & 2013 & - & Genzyme [13] \\
\hline Nusinersen $\left(\right.$ Spinraza $\left.{ }^{\circledR}\right)$ & $\begin{array}{l}\text { 2'-O-Methoxyethyl, } \\
\text { Phosphorothioate, } \\
\text { 5-methyl cytosine }\end{array}$ & Intrathecal & Pre-mRNA & $\begin{array}{l}\text { Spinal muscular } \\
\text { atrophy }\end{array}$ & 2016 & 2017 & Biogen [14] \\
\hline Patisiran (Onpattro ${ }^{\circledR}$ ) & siRNA & Intravenous & $\begin{array}{c}\text { Transthyretin } \\
\text { mRNA }\end{array}$ & $\begin{array}{c}\text { hereditary } \\
\text { transthyretin-mediated } \\
\text { amyloidosis }\end{array}$ & 2018 & 2018 & Alnylam [15] \\
\hline Inotersen $\left(\right.$ Tegsedi ${ }^{\circledR}$ ) & $\begin{array}{l}\text { 2'-O-Methoxyethyl, } \\
\text { Phosphorothioate }\end{array}$ & Subcutaneous & $\begin{array}{c}\text { Transthyretin } \\
\text { mRNA }\end{array}$ & $\begin{array}{c}\text { hereditary } \\
\text { transthyretin-mediated } \\
\text { amyloidosis }\end{array}$ & 2018 & 2018 & Ionis Pharmaceuticals [16] \\
\hline Eteplirsen (Exondys $51^{\circledR}$ ) & $\begin{array}{l}\text { Phosphorodiamidate } \\
\text { morpholino }\end{array}$ & Intravenous & Exon 51 & $\begin{array}{l}\text { Duchenne muscular } \\
\text { dystrophy }\end{array}$ & 2016 & 2018 & Sarepta [17] \\
\hline Golodirsen (Vyondys $53^{\mathrm{TM}}$ ) & $\begin{array}{l}\text { Phosphorodiamidate } \\
\text { morpholino }\end{array}$ & Intravenous & Exon 53 & $\begin{array}{c}\text { Duchenne muscular } \\
\text { dystrophy }\end{array}$ & 2019 & & Sarepta [18] \\
\hline${\text { Givosiran }\left(\text { Givlaari }^{\circledR} \text { ) }\right.}$ & siRNA & Subcutaneous & ALS1 mRNA & Acutehepaticporphyria & 2019 & 2020 & Alnylam [19] \\
\hline Milasen & $\begin{array}{l}\text { 2'-O-Methoxyethyl, } \\
\text { Phosphorothioate, } \\
\text { 5-methyl cytosine }\end{array}$ & Intrathecal & $\begin{array}{c}\text { Intron } 6 \text { spice } \\
\text { acceptor cryptic site }\end{array}$ & $\begin{array}{l}\text { Neuronal ceroid } \\
\text { Lipofuscinosis } 7\end{array}$ & * 2018 & & Boston Children's Hospital [20] \\
\hline Vitolarsen & $\begin{array}{l}\text { Phosphorodiamidate } \\
\text { morpholino }\end{array}$ & Intravenous & Exon 53 & $\begin{array}{c}\text { Duchenne muscular } \\
\text { dystrophy }\end{array}$ & 2020 & & Nippon Shinyaku [21] \\
\hline $\begin{array}{l}\text { Volanesorsen } \\
\text { (Waylivra }^{\circledR} \text { ) }\end{array}$ & $\begin{array}{c}\text { 2'-O-Methoxyethyl, } \\
\text { 5-methyl cytosine, } \\
\text { 2'-deoxy }\end{array}$ & $\begin{array}{l}\text { Subcutaneous } \\
\text { injection }\end{array}$ & Apolipoprotein C3 & $\begin{array}{c}\text { Familial } \\
\text { chylomicronaemia } \\
\text { syndrome }\end{array}$ & & 2019 & Akcea Therapeutics [22] \\
\hline $\begin{array}{c}\text { Casimersen } \\
\text { (Amondys } 45^{\mathrm{TM}} \text { ) }\end{array}$ & $\begin{array}{l}\text { Phosphorodiamidate } \\
\text { morpholino }\end{array}$ & Intravenous & Exon 45 & $\begin{array}{l}\text { Duchenne muscular } \\
\text { dystrophy }\end{array}$ & 2021 & & Sarepta Therapeutics, Inc. [23] \\
\hline
\end{tabular}

* is a personalized medicine developed for a single patient. Generated with data from Dhuri et al. [5] and Crooke et al. [3,4]. 
A quick revision of the drugs approved for utilization in clinics and those in clinical trials shows that most compounds being evaluated do not target bacterial pathogens, and although several groups and companies are working on different strategies [8,24-27], the application of antisense technologies to prokaryotes still lags with respect to those that target other human diseases.

There is a variety of antisense mechanisms of inhibition exploited to design therapies for bacterial infections $[8,9,24,26,28-31]$. In most of these attempts, the antisense compounds target essential genes such that reducing their expression leads to bacterial death or weakening $[8,9,24,26,28,30,31]$. A less common strategy consists of designing antisense compounds that inhibit expression of resistance genes. Therefore, in combination with the appropriate antibiotic, they would act as adjuvants facilitating a successful treatment. The purpose of this short review is to summarize the attempts to develop antisense compounds that inhibit expression of resistance to antibiotics.

The most common mechanisms of antisense oligonucleotide inhibition of gene expression in bacteria are through degradation of the target mRNA by eliciting endogenous RNases like RNase $\mathrm{H}$ or RNase $\mathrm{P}$, or interference with transcription or translation by steric hindrance (Figure 1) $[5,9,24,32]$. Thorough descriptions of different antisense mechanisms of inhibition of gene expression can be found in several excellent recent reviews $[5,9,24,25,33-35]$. In this article, we briefly summarize representative examples of the utilization of antisense strategies to counter antibiotic resistance. Although we subdivided the article in sections based on antisense mechanisms, they should be taken with caution because in numerous cases they have not been confirmed.

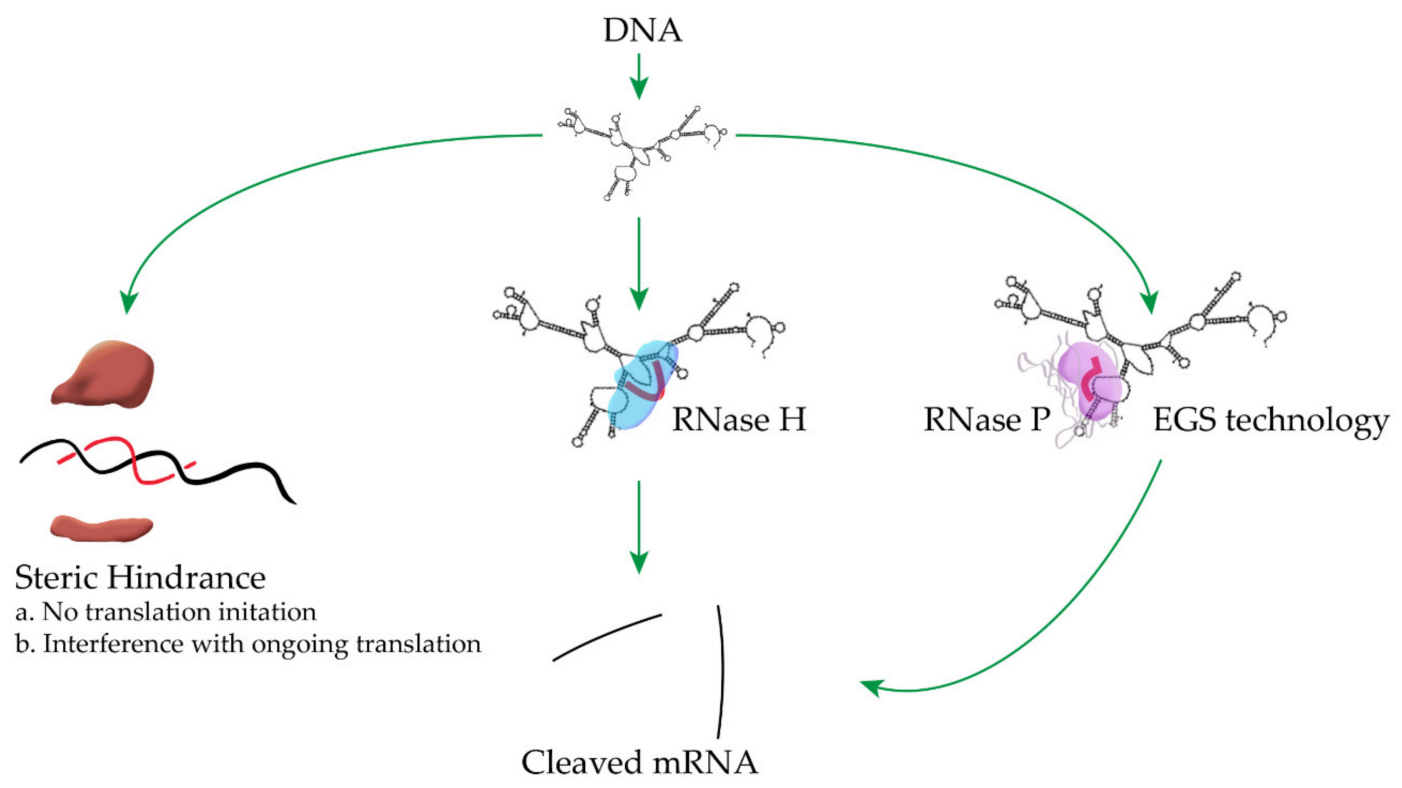

Figure 1. Representative mechanisms of inhibition of gene expression by antisense oligonucleotides. Left-the antisense compound binds the mRNA at the translation initiation region, preventing initiation of translation or at any location of the mRNA, in which case it will interfere with the progress of the ribosome. The figure shows only the binding at the translation initiation region. Center-an antisense oligodeoxynucleotide or analog compatible with activation of RNase $\mathrm{H}$ upon binding to RNA binds a single-stranded region of the target mRNA, which becomes a substrate for cleavage by RNase H. Right-External Guide Sequence (EGS) technology, an antisense oligodeoxynucleotide or analog compatible with activation of RNase P binds a single-stranded region of the target mRNA and forms the structure required to become a substrate of RNase P. Figures that include processes shown in this one can be found in recent reviews $[5,9,24]$.

\section{External Guide Sequence (EGS) Technology}

External Guide Sequence (EGS) technology was intensely researched to design antisense molecules to override resistance. The general mechanism of antisense action in this 
case is of the type of target cleavage. EGS technology takes advantage of the bacterial host's RNAse P. This is a ribozyme present in all organisms that plays many functions, but it was first identified by its catalytic activity that mediates digestion of the immature tRNAs $5^{\prime}$-end termini leading to formation of the mature tRNAs $[36,37]$. The RNA moiety of the enzyme is the catalytic subunit, and, in bacteria, there is usually one cofactor protein [37-39]. The holoenzyme recognizes structural properties in specific regions of the immature tRNA to catalyze the endonucleolytic cleavage [40-42].

A breakthrough for the utilization of RNase P as the basis for an antisense strategy occurred after the finding that most of the immature tRNA molecules could be removed without losing the ability to serve as substrates as long as the key regions and structure are preserved. Furthermore, bimolecular complexes with the appropriate structure, independently of the nucleotide sequence, were also substrates for RNase P [40-42]. These characteristics led to the idea that an oligonucleotide complementary to a target mRNA, provided that after interacting the resulting structure was appropriate, could recruit RNase $\mathrm{P}$ to cleave the latter, reducing the level of expression of the cognate gene $[29,40,43,44]$. Oligonucleotides with these properties are known as external guide sequences (EGSs).

The earliest work that showed the possibility that EGSs could be used as adjuvants to obliterate resistance followed the proof-of-concept experiments in which selected EGSs reduced expression of $\beta$-galactosidase and alkaline phosphatase in Escherichia coli [45]. The sequences of EGSs complementary to bla TEM ( $\beta$-lactamase) and cat (chloramphenicol acetyl transferase) were cloned as part of a DNA fragment consisting of a T7 promoter, the EGS sequence, a core hammerhead sequence, and a T7 terminator (T7p-EGS-HH-T7t). E. coli BL21(DE3) cells carrying these recombinant clones express an RNA fragment containing the EGS and the core hammerhead ribozyme, which directs a self-endonucleolytic cleavage that releases the EGS into the cytosol [46]. Addition of isopropyl $\beta$-d-1-thiogalactopyranoside to the cultures of cell harboring $b l a_{\mathrm{TEM}}$ or cat resulted in a significant reduction of resistance to ampicillin or chloramphenicol [46]. A few years later, Gao et al. confirmed the results of conversion to susceptibility to chloramphenicol in four E. coli strains harboring cat [47].

The early approach described in the previous paragraph was also applied to reduce expression of the $a a c\left(6^{\prime}\right)$ - $I b$ gene, which codes for an acetyltransferase that inactivates amikacin and other clinically important aminoglycosides [48]. The $a a c\left(6^{\prime}\right)-I b$ mRNA was mapped using RNase H mapping and the sites selected as single stranded were used as targets for selection of several EGSs [49]. The most active EGSs were cloned to a DNA arrangement that was the same as that described above and upon introduction into E. coli cells harboring $a a c\left(6^{\prime}\right)-I b$, the levels of resistance were reduced dramatically [49]. In parallel with these advances, it was necessary to explore the activity of antisense oligomers constructed with non-hydrolyzable analogs to prevent degradation. An update on nucleotide analogues has recently been published [50]. The EGSs active in reducing expression of $a a c\left(6^{\prime}\right)-I b$ were tested when they were synthesized using nuclease resistant analogs [51]. Oligomers containing locked nucleic acids (LNAs) (Figure 2) and deoxyribonucleotides in gapmer configuration acted as effective EGSs. Exogenous administration of the locked nucleic acids/deoxyribonucleotides EGSs to the permeable mutant E. coli AS19 strain harboring $a a c\left(6^{\prime}\right)-I b$ resulted in a reduction of levels of amikacin resistance [51]. Comparison of gapmers with different configurations, i.e., with different numbers of analogs at the ends and deoxyribonucleotides in the central region, showed large variations in activity. Furthermore, it was somewhat surprising that similar gapmers in which the LNAs were replaced by the related $2^{\prime}-4^{\prime}$-bridged nucleic acid-NC residues (Figure 2) did not elicit RNase P-mediated degradation of the target mRNA [52]. Other nuclease resistant analogs were incapable of eliciting digestion of the target mRNA [51]. 
<smiles>COP(=O)(O)OC1CC2OC1C2(C)[Mg]</smiles>

Deoxyribonucleotide<smiles>COP(O)(=S)OC1CC2OC1C2(C)[Mg]</smiles>

Phosphorothioate<smiles>COP(=O)(OC)ON1CC(C)OC(C(C)(C)C)C1</smiles>

Phosphoroamidate morpholino

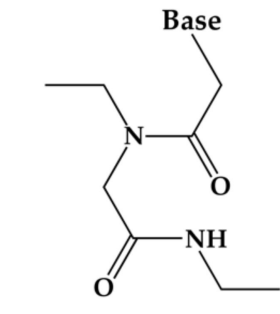

Peptide nucleic acid

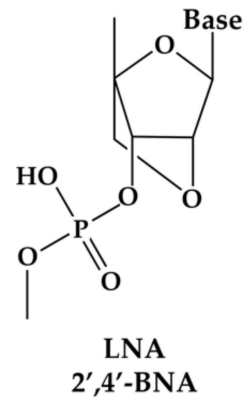

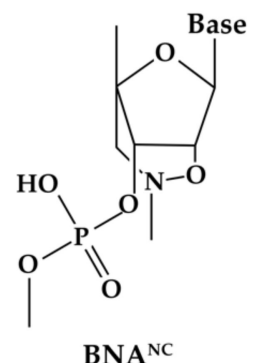

Figure 2. Chemical structures of nucleotide analogs mentioned in the text. The structures shown in this figure were published in the recent article by Soler Bistué et al. [53].

A forward step towards advancing beyond the proof-of-concept stage was the conjugation of EGSs to cell permeabilizer peptides (CPPs) that facilitate uptake of the oligomers by the target bacterial cells. The mechanism by which one CPP facilitates internalization into a Gram-negative bacterial cell was studied using the (KFF) 3 peptide conjugated to a PNA oligomer. The results of these studies showed that CPP is essential for penetrating the outer membrane. Then, $(\mathrm{KFF})_{2}$ or $(\mathrm{KFF})_{3}$ are removed from the conjugate and the PNA oligomer naked or bound to a KFF tripeptide penetrates the inner membrane in a SmbA protein-dependent process [54,55]. Descriptions of mechanisms of internalization and uses of CPPs to transfer cargo inside different kinds of cells can be found in recent reviews [56-59].

While CPPs had been very useful for delivery of a variety of oligonucleotide analogs to diverse cells [56-59], their conjugation to LNAs was challenging due to the charged nature of these analogs and overcoming this stumbling block delayed the possibility of testing LNA-containing oligomers in cells in culture. The active LNA/deoxyribonucleotides gapmers were conjugated to the $(\mathrm{RXR})_{4} \mathrm{XB}(\mathrm{R}$, arginine; $\mathrm{X}, 6$ aminohexanoic acid; $\mathrm{B}$, betaalanine) peptide, a CPP for the delivery of oligonucleotides to bacterial cells $[60,61]$. When these compounds were added to cultures of $A$. baumannii strains that harbor $a a c\left(6^{\prime}\right)-I b$ they produced a reduction in the levels of resistance to amikacin [52,62]. Further studies using a gapmer composed of locked nucleic acids flanking deoxyribonucleotides conjugated to different CPPs showed that these compounds that behaved as active EGSs elicited cleavage of the $a a c\left(6^{\prime}\right)-I b$ mRNA in vitro. However, they had modest activities when tested in different bacteria (Jani et al., manuscript in preparation). Six CPPs were evaluated, (RXR) ${ }_{4} \mathrm{XB}(\mathrm{CPP} 1)$, GRKKRRQRRRPPQ (CPP2), (RFF) ${ }_{3}$ RXB (CPP3), GWTLNSAGYLLGKINLKALAALAKKIL (CPP4), AAVALLPAVLLALLP (CPP5), and TRQARRNRRRRWRERQR (CPP6). The conjugates were tested on K. pneumoniae JHCK1 [63], A. baumannii A155 [64], and E. coli TOP10 (pNW1) [65] cultures containing amikacin. In the case of K. pneumoniae JHCK1 only the conjugate to CPP4 produced significant inhibition of growth (28\%). A. baumannii A155 was inhibited by addition of CPP1 and CPP6 (34.2\% and 34.6\%, respectively), and E. coli TOP10 (pNW1) was inhibited by the addition of CPP1, CPP2, CPP5, and CPP6 (40.1\%, $21.6 \%, 42.1 \%$, and $37.6 \%$, respectively). 
Inhibition of the cat gene was also observed using EGSs conjugated to a CPP, in which the oligonucleotide moiety was constructed with phosphorodiamidate morpholino residues (Figure 2) [66]. Two EGSs conjugated to CPPs, with sequences targeting different locations of the cat mRNA, were tested in experiments where E. coli cells in rich medium containing chloramphenicol were mixed with the compounds. After four hours, the number of surviving cells was determined, and the results showed potent activity by each of the antisense compounds and a higher efficiency when both compounds were used together [66]. An EGS targeting the bla TEM conjugated to a CPP was also effective in inhibiting resistance to ampicillin in E. coli cells after mixing the compound with the cells suspended in culture medium [67].

\section{RNase $H$}

Degradation of an mRNA target by RNase $\mathrm{H}$ is an important mechanism utilized to silence genes through antisense oligomers. RNase $\mathrm{H}$ is an enzyme present in all living organisms that is characterized by its endonucleolytic cleavage of RNA when it is in duplex

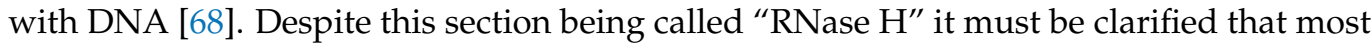
examples described in it have the potential to act through activation of this enzyme, but confirmation is lacking. Oligodeoxynucleotides or analogs compatible with the enzymatic activity are used to direct cleavage of the target mRNA. White al. [69] utilized antisense phosphorothioate oligodeoxynucleotides (Figure 2), which are known to induce RNase H degradation of RNA in duplex [70], to reduce the resistance to norfloxacin mediated by the expression of the multiple antibiotic resistance (mar) locus in E. coli. The mar locus includes two divergent transcriptional units, $\operatorname{mar} C$ and $\operatorname{mar} R A B$, that are transcribed from a central regulatory region occupied by the marO, a regulatory locus [71]. An antisense phosphorothioate oligonucleotide that reduced expression of the transcriptional activator MarA was associated with the increase in susceptibility to norfloxacin. However, this work required the introduction of the antisense compounds by chemical transformation or electroporation and the mechanism of inhibition was not confirmed to be through activation of RNase H. Thus, steric hindrance remains a possibility [69]. Similar successes and limitations in the understanding of the mechanism of action were observed in work carried out to inhibit expression of the $a a c\left(6^{\prime}\right)$ - Ib gene using oligodeoxynucleotides and internalizing them into the bacterial cells through electroporation [65].

Inhibition of multiple drug resistance was achieved by antisense inhibition of expression of the Pseudomonas aeruginosa MexAB-OprM efflux pump [72]. Accumulation of the components of this pump are associated with resistance to numerous antibiotics such as $\beta$ lactams, macrolides, quinolones, tetracycline, and chloramphenicol $[73,74]$. MexAB-OprM belongs to the resistance-nodulation-cell division (RND) superfamily, and it is one of many efflux pumps that can be harbored by P. aeruginosa [75]. MexAB-OprM includes MexB, an inner membrane transporter, OprM, an outer membrane protein, and MexA, which connects MexB with OprM. The structure of this pump and a model mechanism of drug efflux were recently proposed [74]. A phosphorothioate oligodeoxynucleotide antisense to the oprM mRNA was encapsulated in anionic liposomes as a delivery for internalization inside the bacterial cells [72]. Several clinical P. aeruginosa strains were tested and addition of the antisense resulted in a reduction of resistance levels to piperacillin, ciprofloxacin, levofloxacin, cefoperazone, imipenem, and amikacin in all cases. Unfortunately, the mechanism of inhibition has not yet been confirmed to be through cleavage of the target mRNA by RNase H. It is noteworthy that this work describes a novel anion liposome composition for encapsulation and delivery of oligonucleotides inside the bacterial cells. Liposomes were used scarcely in the past with these purposes, but new advances, including conjugation of the oligonucleotide molecule to the lipid, may increase their utilization in the future [76-78]. In particular, an oligonucleotide conjugated to a lipid moiety has recently proved effective in reducing the resistance level to ceftriaxone in E. coli cells harboring

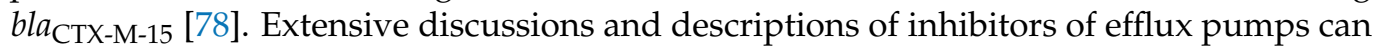
be found in recent reviews $[27,79,80]$. 


\section{Steric Hindrance}

Besides EGS technology, inhibition of resistance to ampicillin mediated by $b l a_{\mathrm{TEM}}$ was also explored using other antisense techniques. One of the earliest attempts at inhibition of expression of bla $a_{\text {TEM }}$ utilized oligodeoxynucleotides covalently linked to a 9-aminoacridine derivative, which also proved capable of inhibiting the expression of $b l a_{\mathrm{TEM}}$. The stability of the complexes between the complementary sequence of the oligonucleotide and the target was increased due to intercalation of the 9-aminoacridine derivative [81]. In this case, inhibition of gene expression occurs by interference with transcription initiation when the antisense compound binds to the transcribed strand in the open complex formed by E. coli RNA polymerase with the promoter [81]. Another approach consisted of a photoactivatable oligonucleotide-containing psoralen monoadducts. E. coli harboring bla TEM became more susceptible to ampicillin after exposure to a photoactivated antisense 9-mer oligonucleotide bound to a psoralen $4^{\prime}, 5^{\prime}$-monoadduct [82]. Inhibition of expression of bla TEM was also achieved using 15-mer peptide nucleic acid (PNA) oligomers (Figure 2) [83]. PNAs are oligodeoxynucleotide analogs in which the deoxyribose phosphodiester of DNA was replaced by a pseudo-peptide backbone. As a consequence, unlike DNA and RNA, which are negatively charged, PNA is a neutral compound [84]. PNA binds DNA and RNA with very high affinity, can be conjugated to CPPs, and has shown low toxicity [85,86]. PNA can interfere with gene expression, preventing transcription by binding to a DNA target or translation by binding to the target mRNA [87]. The pioneering work by Good and Nielsen where an antisense PNA targeting the $b l a_{\text {TEM }}$ gene reversed resistance to ampicillin utilized the PNA oligomers without any helper for internalization inside the cells. As a consequence, these authors carried out the assays using the permeable mutant $E$. coli AS19 [83].

Resistance to oxacillin was also reversed by the utilization of PNA antisense oligonucleotides in the methicillin-resistant Staphylococcus aureus and methicillin-resistant Staphylococcus pseudintermedius [88]. The antisense compounds were conjugated to three different CPPs, KFFKFFKFFK, MINWKLRLKNK, and YGRKKRRQRRR but no significant differences were found in reversion of resistance. Interestingly, measurement of the mRNA levels showed a low but significant reduction in cells treated with the antisense. This could have been a somewhat unexpected observation because PNA analogs are known not to induce RNase $\mathrm{H}$ cleavage. However, the phenotypic effect, i.e., reduction in resistance levels, was large, suggesting that the main mechanism of inhibition is mainly interference with protein translation [88-90].

Carbapenems are among the antibiotics of last resort for treatment of multidrug infections. Therefore, all efforts must be made to limit development and dissemination of resistance. The most common mechanism of resistance to carbapenems in the clinics is the presence of carbapenemases [91,92]. Other means by which bacteria resist these antibiotics are the action of efflux pumps, modification in expression or synthesis of new penicillinbinding proteins, and reduction or inactivation of expression of porins. In an effort to inhibit expression of the New Delhi metallo- $\beta$-lactamase (NDM-1), Sully et al. [93] designed antisense phosphorodiamidate morpholino oligomers conjugated to the CPP (RXR $)_{4} \mathrm{XB}$. The antisense sequence was complementary to the translation initiation region of $b l a_{\mathrm{NDM}-1}$. The phosphorodiamidate morpholino are nucleotide analogs known to interfere with gene expression by steric hindrance. These analogs do not elicit RNase $\mathrm{H}$ degradation of the target mRNA. Addition of this compound to cultures of $E$. coli strains harboring $b l a_{\mathrm{NDM}-1}$ produced inhibition of expression of the gene and susceptibility to meropenem [93].

PNA antisense compounds were also used to interfere with translation of the $\mathrm{CmeA}$ protein. This is the periplasmic component of the Campylobacter jejuni CmeABC efflux pump, which belongs to the RND superfamily. The PNA antisense was conjugated to a CPP, KFFKFFKFFK, and the inhibition of CmeA expression was confirmed by immunoblot analysis. This antisense compound, when added at $2 \mu \mathrm{M}$, was associated with a reduction of eight- and four-fold in the C. jejuni minimal inhibitory concentrations (MICs) of 
ciprofloxacin and erythromycin, respectively [94]. Extended descriptions of inhibitors of efflux pumps were recently published.

A recent approach to designing antisense compounds was recently reported. It consists of a novel semiautomated pipeline for the design, synthesis, and testing of antisense PNAs (Facile Accelerated Specific Therapeutic, FAST) [95]. This methodology is not only rapid, but it results in highly specific antisense sequences. The authors utilized the platform to design antisense compounds that act as antibiotics against five multidrug resistant Enterobacteriaceae clinical isolates and an antisense compound that modifies the action of carbapenem against a carbapenem-resistant $E$. coli strain $[95,96]$. In the latter case, the target genes were selected following a novel approach. The authors determined the expression profiles of an ertapenem-resistant, meropenem-susceptible E. coli strain cultured in the presence of one or the other antibiotic. Genes that showed significant expression levels in response to the presence of the antibiotic were selected as targets for FAST design of antisense PNA compounds, which were conjugated to a CPP for testing. Antisensemediated inhibition of the genes $h y c A$ (regulatory protein in the formate hydrogenlyase system), $d s r B$ (unknown function), and bolA (transcriptional regulator of several genes) potentiated carbapenem efficacy while inhibition of the genes flhC (transcriptional regulator of motility related functions) and ygaC (uknown function) resulted added resistance [95].

PNA oligomers conjugated to $(\mathrm{KFF})_{3}$ designed to target the ribosome-binding site of mcr-1 restores susceptibility to colistin in E. coli [97].

\section{Final Remarks}

Bacterial infections are a leading cause of death, compromised health, and disability worldwide [98]. Outbreaks of bacterial infection continue to occur, and the etiologic agents are commonly resistant to multiple antibiotics $[99,100]$. Furthermore, the increase in the number of antibiotic-resistant bacterial pathogens not only affects our ability to treat infectious diseases and impose an economic burden on the health system, but also complicates medical procedures that depend on prevention of infection such as surgery, treatment of cancer and other chronic diseases, organ transplants, dental work, and care for premature infants [101-104]. Despite the dire situation, researchers responded to the call for action by diverse health organizations. New strategies are being developed to continue to produce new therapies to keep pace with the accelerated rise of antibiotic resistance [105]. One of the options explored to generate new therapies that can overcome multidrug resistance is utilizing diverse antisense oligonucleotides. This technologies' versatility permits us to envision the generation of antisense drugs that either have antibiotic activity or that disable resistance to certain antimicrobials and act as adjuvants. The high diversity of the chemistries of the nucleotide analogs used to synthesize the complementary oligonucleotide in conjunction with the different modes of action and the variety of internalization methods offer a field full of possibilities for these compounds to join the armamentarium to fight multidrug resistance. We are confident that the coming years will see the first antisense adjuvant/antibiotic formulations become a reality.

Author Contributions: S.J., M.S.R., and M.E.T. wrote and revised the manuscript. All authors approved the final version of the paper. All authors have read and agreed to the published version of the manuscript.

Funding: Work included in this review that was carried out in the authors' laboratories was supported by the National Institutes of Health grant 2R15 AI047115 from the National Institute of Allergy and Infectious Diseases (to MET) and SC3GM125556 from the National Institute of General Medical Sciences (to MSR). The content of this paper is solely the responsibility of the authors and does not necessarily represent the official views of the NIH.

Institutional Review Board Statement: Not applicable.

Informed Consent Statement: Not applicable.

Data Availability Statement: Not applicable. 
Acknowledgments: The authors thank their respective laboratory members (past and present) for their contributions to their research projects.

Conflicts of Interest: The authors declare no conflict of interest.

\section{References}

1. Zamecnik, P.C.; Stephenson, M.L. Inhibition of Rous sarcoma virus replication and cell transformation by a specific oligodeoxynucleotide. Proc. Natl. Acad. Sci. USA 1978, 75, 280-284. [CrossRef] [PubMed]

2. Marwick, C. First "Antisense" Drug Will Treat CMV Retinitis. JAMA 1998, 280, 871. [CrossRef]

3. Crooke, S.T.; Baker, B.F.; Crooke, R.M.; Liang, X.-H. Antisense technology: An overview and prospectus. Nat. Rev. Drug Discov. 2021, 1-27. [CrossRef]

4. Crooke, S.T.; Liang, X.-H.; Baker, B.F.; Crooke, R.M. Antisense technology: A review. J. Biol. Chem. 2021, 296, 100416. [CrossRef] [PubMed]

5. Dhuri, K.; Bechtold, C.; Quijano, E.; Pham, H.; Gupta, A.; Vikram, A.; Bahal, R. Antisense oligonucleotides: An emerging area in drug discovery and development. J. Clin. Med. 2020, 9, 2004. [CrossRef] [PubMed]

6. Sridharan, K.; Gogtay, N.J. Therapeutic nucleic acids: Current clinical status. Br. J. Clin. Pharmacol. 2016, 82, 659-672. [CrossRef]

7. Scharner, J.; Aznarez, I. Clinical applications of single-stranded oligonucleotides: Current landscape of approved and indevelopment therapeutics. Mol. Ther. 2021, 29, 540-554. [CrossRef]

8. Pifer, R.; Greenberg, D.E. Antisense antibacterial compounds. Transl. Res. 2020, 223, 89-106. [CrossRef]

9. Rasmussen, L.C.V.; Sperling-Petersen, H.U.; Mortensen, K.K. Hitting bacteria at the heart of the central dogma: Sequence-specific inhibition. Microb. Cell Factories 2007, 6, 24-26. [CrossRef]

10. Titze-De-Almeida, R.; David, C.; Titze-De-Almeida, S.S. The race of 10 synthetic RNAi-based drugs to the pharmaceutical market. Pharm. Res. 2017, 34, 1339-1363. [CrossRef]

11. Bonneau, E.; Neveu, B.; Kostantin, E.; Tsongalis, G.J.; De Guire, V. How close are miRNAs from clinical practice? A perspective on the diagnostic and therapeutic market. Electron. J. Int. Fed. Clin. Chem. Lab. Med. 2019, 30, 114-127.

12. Drury, R.E.; O'Connor, D.; Pollard, A.J. The clinical application of microRNAs in infectious disease. Front. Immunol. 2017, 8, 1182. [CrossRef] [PubMed]

13. Raal, F.J.; Santos, R.D.; Blom, D.J.; Marais, A.D.; Charng, M.-J.; Cromwell, W.C.; Lachmann, R.H.; Gaudet, D.; Tan, J.L.; ChasanTaber, S.; et al. Mipomersen, an apolipoprotein B synthesis inhibitor, for lowering of LDL cholesterol concentrations in patients with homozygous familial hypercholesterolaemia: A randomised, double-blind, placebo-controlled trial. Lancet 2010, 375, 998-1006. [CrossRef]

14. Acsadi, G.; Crawford, T.O.; Müller-Felber, W.; Shieh, P.B.; Richardson, R.; Natarajan, N.; Castro, D.; Ramirez-Schrempp, D.; Gambino, G.; Sun, P.; et al. Safety and efficacy of nusinersen in spinal muscular atrophy: The EMBRACE study. Muscle Nerve 2021. [CrossRef]

15. Urits, I.; Swanson, D.; Swett, M.C.; Patel, A.; Berardino, K.; Amgalan, A.; Berger, A.A.; Kassem, H.; Kaye, A.D.; Viswanath, O. A review of Patisiran $\left(\right.$ ONPATTRO $\left.{ }^{\circledR}\right)$ for the treatment of polyneuropathy in people with hereditary transthyretin amyloidosis. Neurol. Ther. 2020, 9, 301-315. [CrossRef] [PubMed]

16. Mahfouz, M.; Maruyama, R.; Yokota, T. Inotersen for the treatment of hereditary transthyretin amyloidosis. Methods in Molecular Biology 2020, 2176, 87-98. [CrossRef] [PubMed]

17. Mendell, J.R.; Goemans, N.; Lowes, L.P.; Alfano, L.N.; Berry, K.; Shao, J.; Kaye, E.M.; Mercuri, E.; Eteplirsen Study Group; Telethon Foundation DMD Italian Network. Longitudinal effect of eteplirsen versus historical control on ambulation in Duchenne muscular dystrophy. Ann. Neurol. 2016, 79, 257-271. [CrossRef]

18. Heo, Y.A. Golodirsen: First approval. Drugs 2020, 80, 329-333. [CrossRef] [PubMed]

19. Balwani, M.; Sardh, E.; Ventura, P.; Peiró, P.A.; Rees, D.C.; Stölzel, U.; Bissell, D.M.; Bonkovsky, H.L.; Windyga, J.; Anderson, K.E.; et al. Phase 3 trial of RNAi therapeutic Givosiran for acute intermittent porphyria. New Engl. J. Med. 2020, 382, $2289-2301$. [CrossRef]

20. Kim, J.; Hu, C.; El Achkar, C.M.; Black, L.E.; Douville, J.; Larson, A.; Pendergast, M.K.; Goldkind, S.F.; Lee, E.A.; Kuniholm, A.; et al. Patient-customized oligonucleotide therapy for a rare genetic disease. New Engl. J. Med. 2019, 381, 1644-1652. [CrossRef]

21. Komaki, H.; Takeshima, Y.; Matsumura, T.; Ozasa, S.; Funato, M.; Takeshita, E.; Iwata, Y.; Yajima, H.; Egawa, Y.; Toramoto, T.; et al. Viltolarsen in Japanese Duchenne muscular dystrophy patients: A phase 1/2 study. Ann. Clin. Transl. Neurol. 2020, 7, $2393-2408$. [CrossRef] [PubMed]

22. Paik, J.; Duggan, S. Volanesorsen: First Global Approval. Drugs 2019, 79, 1349-1354. [CrossRef]

23. Rodrigues, M.; Yokota, T. An overview of recent advances and clinical applications of exon skipping and splice modulation for muscular dystrophy and various genetic diseases. Methods Mol. Biol. 2018, 1828, 31-55. [CrossRef] [PubMed]

24. Sully, E.K.; Geller, B.L. Antisense antimicrobial therapeutics. Curr. Opin. Microbiol. 2016, 33, 47-55. [CrossRef] [PubMed]

25. Dinan, A.M.; Loftus, B.J. (Non-)translational medicine: Targeting bacterial RNA. Front. Genet. 2013, 4, 230. [CrossRef] [PubMed]

26. Goltermann, L.; Nielsen, P.E. PNA Antisense Targeting in Bacteria: Determination of Antibacterial Activity (MIC) of PNA-Peptide Conjugates. In Methods in Molecular Biology; Springer: Berlin/Heidelberg, Germany, 2020; pp. 231-239.

27. Tolmasky, M.E. Strategies to prolong the useful life of existing antibiotics and help overcoming the antibiotic resistance crisis In Frontiers in Clinical Drug Research-Anti Infectives; Atta-ur-Rhaman, Ed.; Bentham Books: Sharjah, UAE, 2017; Volume 1. 
28. Davies-Sala, C.; Soler-Bistué, A.; Bonomo, R.A.; Zorreguieta, A.; Tolmasky, M.E. External guide sequence technology: A path to development of novel antimicrobial therapeutics. Ann. N. Y. Acad. Sci. 2015, 1354, 98-110. [CrossRef] [PubMed]

29. Sala, C.D.; Soler-Bistué, A.J.C.; Korprapun, L.; Zorreguieta, A.; Tolmasky, M.E. Inhibition of Cell Division Induced by External Guide Sequences (EGS Technology) Targeting ftsZ. PLoS ONE 2012, 7, e47690. [CrossRef]

30. Streicher, L.M. Exploring the future of infectious disease treatment in a post-antibiotic era: A comparative review of alternative therapeutics. J. Glob. Antimicrob. Resist. 2021, 24, 285-295. [CrossRef]

31. Vogel, J. An RNA biology perspective on species-specific programmable RNA antibiotics. Mol. Microbiol. 2020, 113, 550-559. [CrossRef]

32. Kole, R.; Krainer, A.R.; Altman, S. RNA therapeutics: Beyond RNA interference and antisense oligonucleotides. Nat. Rev. Drug Discov. 2012, 11, 125-140. [CrossRef]

33. Malik, R.; Roy, I. Making sense of therapeutics using antisense technology. Expert Opin. Drug Discov. 2011, 6, 507-526. [CrossRef] [PubMed]

34. Quemener, A.M.; Bachelot, L.; Forestier, A.; Donnou-Fournet, E.; Gilot, D.; Galibert, M. The powerful world of antisense oligonucleotides: From bench to bedside. Wiley Interdiscip. Rev. RNA 2020, 11, e1594. [CrossRef]

35. Good, L.; Stach, J.E.M. Synthetic RNA silencing in bacteria? Antimicrobial discovery and resistance breaking. Front. Microbiol. 2011, 2, 185. [CrossRef] [PubMed]

36. Guerrier-Takada, C.; Gardiner, K.; Marsh, T.; Pace, N.; Altman, S. The RNA moiety of ribonuclease P is the catalytic subunit of the enzyme. Cell 1983, 35, 849-857. [CrossRef]

37. Altman, S. A view of RNase P. Mol. BioSyst. 2007, 3, 604-607. [CrossRef]

38. Mondragón, A. Structural Studies of RNase P. Annu. Rev. Biophys. 2013, 42, 537-557. [CrossRef] [PubMed]

39. Reiter, N.J.; Osterman, A.; Torres-Larios, A.; Swinger, K.K.; Pan, T.; Mondragón, A. Structure of a bacterial ribonuclease P holoenzyme in complex with tRNA. Nat. Cell Biol. 2010, 468, 784-789. [CrossRef] [PubMed]

40. Gopalan, V.; Vioque, A.; Altman, S. RNase P: Variations and Uses. J. Biol. Chem. 2002, 277, 6759-6762. [CrossRef]

41. Kirsebom, L.A. RNase P RNA mediated cleavage: Substrate recognition and catalysis. Biochim. 2007, 89, 1183-1194. [CrossRef]

42. Kirsebom, L.A.; Svärd, S.G. The kinetics and specificity of cleavage by RNase P is mainly dependent on the structure of the amino acid acceptor stem. Nucleic Acids Res. 1992, 20, 425-432. [CrossRef]

43. Forster, A.C.; Altman, S. External guide sequences for an RNA enzyme. Sci. 1990, 249, 783-786. [CrossRef]

44. Lundblad, E.W.; Altman, S. Inhibition of gene expression by RNase P. New Biotechnol. 2010, 27, 212-221. [CrossRef] [PubMed]

45. Guerrier-Takada, C.; Li, Y.; Altman, S. Artificial regulation of gene expression in Escherichia coli by RNase P. Proc. Natl. Acad. Sci. USA 1995, 92, 11115-11119. [CrossRef]

46. Guerrier-Takada, C.; Salavati, R.; Altman, S. Phenotypic conversion of drug-resistant bacteria to drug sensitivity. Proc. Natl. Acad. Sci. USA 1997, 94, 8468-8472. [CrossRef] [PubMed]

47. Gao, M.-Y.; Xu, C.-R.; Chen, R.; Liu, S.-G.; Feng, J.-N. Chloromycetin resistance of clinically isolated $E$ coli is conversed by using EGS technique to repress the chloromycetin acetyl transferase. World J. Gastroenterol. 2005, 11, 7368-7373. [CrossRef] [PubMed]

48. Ramirez, M.S.; Tolmasky, M.E. Aminoglycoside modifying enzymes. Drug Resist. Updat. 2010, 13, 151-171. [CrossRef]

49. Bistué, A.J.C.S.; Ha, H.; Sarno, R.; Don, M.; Zorreguieta, A.; Tolmasky, M.E. External guide sequences targeting the $a a c\left(6^{\prime}\right)$-Ib mRNA induce inhibition of amikacin resistance. Antimicrob. Agents Chemother. 2007, 51, 1918-1925. [CrossRef]

50. Agrawal, S.; Gait, M.J. CHAPTER 1. History and development of nucleotide analogues in nucleic acids drugs. In Drug Discovery; Royal Society of Chemistry (RSC): Cambridge, UK, 2019; pp. 1-21.

51. Bistue, A.J.C.S.; Martin, F.A.; Vozza, N.; Ha, H.; Joaquin, J.C.; Zorreguieta, A.; Tolmasky, M.E. Inhibition of aac(6')-Ib-mediated amikacin resistance by nuclease-resistant external guide sequences in bacteria. Proc. Natl. Acad. Sci. USA 2009, 106, 13230-13235. [CrossRef]

52. Jackson, A.; Jani, S.; Davies-Sala, C.; Soler-Bistué, A.J.C.; Zorreguieta, A.; E Tolmasky, M. Assessment of configurations and chemistries of bridged nucleic acids-containing oligomers as external guide sequences: A methodology for inhibition of expression of antibiotic resistance genes. Biol. Methods Protoc. 2016, 1, 1. [CrossRef]

53. Soler-Bistué, A.; Zorreguieta, A.; Tolmasky, M.E. Bridged Nucleic Acids Reloaded. Molecules 2019, 24, 2297. [CrossRef]

54. Ghosal, A.; Vitali, A.; Stach, J.E.; Nielsen, P.E. Role of SbmA in the uptake of peptide nucleic acid (PNA)-peptide conjugates in E. coli. ACS Chem. Biol. 2012, 8, 360-367. [CrossRef] [PubMed]

55. Yavari, N.; Goltermann, L.; Nielsen, P.E. Uptake, stability, and activity of antisense anti-acpP PNA-peptide conjugates in Escherichia coli and the role of SbmA. ACS Chem. Biol. 2021, 16, 471-479. [CrossRef] [PubMed]

56. Boisguérin, P.; Deshayes, S.; Gait, M.J.; O’Donovan, L.; Godfrey, C.; Betts, C.A.; Wood, M.J.; Lebleu, B. Delivery of therapeutic oligonucleotides with cell penetrating peptides. Adv. Drug Deliv. Rev. 2015, 87, 52-67. [CrossRef] [PubMed]

57. Copolovici, D.M.; Langel, K.; Eriste, E.; Langel, Ü. Cell-Penetrating Peptides: Design, Synthesis, and Applications. ACS Nano 2014, 8, 1972-1994. [CrossRef] [PubMed]

58. Reissmann, S. Cell penetration: Scope and limitations by the application of cell-penetrating peptides. J. Pept. Sci. 2014, $20,760-784$. [CrossRef] [PubMed]

59. Kurrikoff, K.; Vunk, B.; Langel, Ü. Status update in the use of cell-penetrating peptides for the delivery of macromolecular therapeutics. Expert Opin. Biol. Ther. 2021, 21, 361-370. [CrossRef] [PubMed] 
60. Lehto, T.; Ezzat, K.; Wood, M.J.; EL Andaloussi, S. Peptides for nucleic acid delivery. Adv. Drug Deliv. Rev. 2016, 106, 172-182. [CrossRef]

61. Puckett, S.E.; Reese, K.A.; Mitev, G.M.; Mullen, V.; Johnson, R.C.; Pomraning, K.R.; Mellbye, B.L.; Tilley, L.D.; Iversen, P.L.; Freitag, M.; et al. Bacterial resistance to antisense peptide phosphorodiamidate morpholino oligomers. Antimicrob. Agents Chemother. 2012, 56, 6147-6153. [CrossRef]

62. Jani, S.; Jackson, A.; Davies-Sala, C.; Chiem, K.; Soler-Bistué, A.; Zorreguieta, A.; Tolmasky, M.E. Assessment of external guide sequences' (EGS) efficiency as inducers of RNase P-mediated cleavage of mRNA target molecules. Methods Mol. Biol. 2018, 1737, 89-98. [CrossRef] [PubMed]

63. Ramirez, M.S.; Xie, G.; Marshall, S.H.; Hujer, K.M.; Chain, P.S.G.; Bonomo, R.A.; Tolmasky, M.E. Multidrug-resistant (MDR) Klebsiella pneumoniae clinical isolates: A zone of high heterogeneity (HHZ) as a tool for epidemiological studies. Clin. Microbiol. Infect. 2012, 18, E254-E258. [CrossRef]

64. Arivett, B.A.; Fiester, S.E.; Ream, D.C.; Centrón, D.; Ramírez, M.S.; Tolmasky, M.E.; Actis, L.A. Draft genome of the multidrugresistant Acinetobacter baumannii strain A155 clinical isolate. Genome Announc. 2015, 3, e00212-e00215. [CrossRef] [PubMed]

65. Sarno, R.; Ha, H.; Weinsetel, N.; Tolmasky, M.E. Inhibition of aminoglycoside 6 ' $-N$-acetyltransferase type Ib-mediated amikacin resistance by antisense oligodeoxynucleotides. Antimicrob. Agents Chemother. 2003, 47, 3296-3304. [CrossRef] [PubMed]

66. Shen, N.; Ko, J.-H.; Xiao, G.; Wesolowski, N.; Shan, G.; Geller, B.; Izadjoo, M.; Altman, S. Inactivation of expression of several genes in a variety of bacterial species by EGS technology. Proc. Natl. Acad. Sci. USA 2009, 106, 8163-8168. [CrossRef] [PubMed]

67. Wesolowski, D.; Alonso, D.; Altman, S. Combined effect of a peptide-morpholino oligonucleotide conjugate and a cell-penetrating peptide as an antibiotic. Proc. Natl. Acad. Sci. USA 2013, 110, 8686-8689. [CrossRef] [PubMed]

68. Hyjek, M.; Figiel, M.; Nowotny, M. RNases H: Structure and mechanism. DNA Repair 2019, 84, 102672. [CrossRef]

69. White, D.G.; Maneewannakul, K.; Von Hofe, E.; Zillman, M.; Eisenberg, W.; Field, A.K.; Levy, S.B. Inhibition of the multiple antibiotic resistance (mar) operon in Escherichia coli by antisense DNA analogs. Antimicrob. Agents Chemother. 1997, 41, 2699-2704. [CrossRef]

70. Burnett, J.C.; Rossi, J.J. RNA-based therapeutics: Current progress and future prospects. Chem. Biol. 2012, 19, 60-71. [CrossRef]

71. Blanco, P.; Hernando-Amado, S.; Reales-Calderon, J.A.; Corona, F.; Lira, F.; Alcalde-Rico, M.; Bernardini, A.; Sanchez, M.B.; Martinez, J.L. Bacterial multidrug efflux pumps: Much more than antibiotic resistance determinants. Microorganisms 2016, 4, 14. [CrossRef]

72. Wang, H.; Meng, J.; Jia, M.; Ma, X.; He, G.; Yu, J.; Wang, R.; Bai, H.; Hou, Z.; Luo, X. oprMas a new target for reversion of multidrug resistance inPseudomonas aeruginosaby antisense phosphorothioate oligodeoxynucleotides. FEMS Immunol. Med Microbiol. 2010, 60, 275-282. [CrossRef]

73. Li, X.Z.; Nikaido, H.; Poole, K. Role of mexA-mexB-oprM in antibiotic efflux in Pseudomonas aeruginosa. Antimicrob. Agents Chemother. 1995, 39, 1948-1953. [CrossRef] [PubMed]

74. Tsutsumi, K.; Yonehara, R.; Ishizaka-Ikeda, E.; Miyazaki, N.; Maeda, S.; Iwasaki, K.; Nakagawa, A.; Yamashita, E. Structures of the wild-type MexAB-OprM tripartite pump reveal its complex formation and drug efflux mechanism. Nat. Commun. 2019, 10, 1-10. [CrossRef]

75. Phan, G.; Picard, M.; Broutin, I. Focus on the outer membrane factor OprM, the forgotten player from efflux pumps assemblies. Antibiotics 2015, 4, 544-566. [CrossRef] [PubMed]

76. Fillion, P.; Desjardins, A.; Sayasith, K.; Lagacé, J. Encapsulation of DNA in negatively charged liposomes and inhibition of bacterial gene expression with fluid liposome-encapsulated antisense oligonucleotides. Biochim Biophys Acta. 2001, 1515, 44-54. [CrossRef]

77. Pereira, S.; Santos, R.S.; Moreira, L.; Guimarães, N.M.; Braeckmans, K.; De Smedt, S.C.; Azevedo, N.F. Delivery of oligonucleotides into bacteria by fusogenic liposomes. Methods Mol. Biol. 2021, 2246, 87-96. [PubMed]

78. Kauss, T.; Arpin, C.; Bientz, L.; Nguyen, P.V.; Vialet, B.; Benizri, S.; Barthélémy, P. Lipid oligonucleotides as a new strategy for tackling the antibiotic resistance. Sci. Rep. 2020, 10, 1054-1059. [CrossRef] [PubMed]

79. Pathania, R.; Sharma, A.; Gupta, V.K. Efflux pump inhibitors for bacterial pathogens: From bench to bedside. Indian J. Med Res. 2019, 149, 129-145. [CrossRef] [PubMed]

80. Mahmood, H.Y.; Jamshidi, S.; Sutton, J.M.; Rahman, K.M. Current advances in developing inhibitors of bacterial multidrug efflux pumps. Curr. Med. Chem. 2016, 23, 1062-1081. [CrossRef]

81. Helene, C.; Montenay-Garestier, T.; Saison, T.; Takasugi, M.; Toulme, J.-J.; Asseline, U.; Lancelot, G.; Maurizot, J.; Toulme, F.; Thuong, N. Oligodeoxynucleotides covalently linked to intercalating agents: A new class of gene regulatory substances. Biochimie 1985, 67, 777-783. [CrossRef]

82. Gasparro, F.; Edelson, R.; O’Malley, M.; Ugent, S.; Wong, H. Photoactivatable antisense DNA: Suppression of ampicillin resistance in normally resistant Escherichia coli. Antisense Res. Dev. 1991, 1, 117-140. [CrossRef]

83. Good, L.; Nielsen, P.E. Antisense inhibition of gene expression in bacteria by PNA targeted to mRNA. Nat. Biotechnol. 1998, 16, 355-358. [CrossRef] [PubMed]

84. E Nielsen, P.; Egholm, M. An introduction to peptide nucleic acid. Curr. Issues Mol. Biol. 1999, 1, 89-104.

85. Nielsen, P.E. Gene targeting and expression modulation by peptide nucleic acids (PNA). Curr. Pharm. Des. 2010, 16, 3118-3123. [CrossRef] 
86. Lundin, K.E.; Good, L.; Strömberg, R.; Gräslund, A.; Smith, C.I.E. Biological activity and biotechnological aspects of peptide nucleic acid. Nat. Var. Clocks 2006, 56, 1-51. [CrossRef]

87. Lee, H.T.; Kim, S.K.; Yoon, J.W. Antisense peptide nucleic acids as a potential anti-infective agent. J. Microbiol. 2019, 57, 423-430. [CrossRef] [PubMed]

88. Goh, S.; Loeffler, A.; Lloyd, D.H.; Nair, S.P.; Good, L. Oxacillin sensitization of methicillin-resistant Staphylococcus aureus and methicillin-resistant Staphylococcus pseudintermedius by antisense peptide nucleic acids in vitro. BMC Microbiol. 2015, 15, 262. [CrossRef] [PubMed]

89. Bai, H.; Sang, G.; You, Y.; Xue, X.; Zhou, Y.; Hou, Z.; Meng, J.; Luo, X. Targeting RNA polymerase primary $\sigma 70$ as a therapeutic strategy against methicillin-resistant Staphylococcus aureus by antisense peptide nucleic acid. PLoS ONE 2012, 7, e29886. [CrossRef] [PubMed]

90. Goh, S.; Boberek, J.M.; Nakashima, N.; Stach, J.; Good, L. Concurrent growth rate and transcript analyses reveal essential gene stringency in Escherichia coli. PLoS ONE 2009, 4, e6061. [CrossRef]

91. Bush, K.; Bradford, P.A. Epidemiology of $\beta$-lactamase-producing pathogens. Clin. Microbiol. Rev. 2020, 33. [CrossRef]

92. Ramirez, M.S.; Bonomo, R.A.; Tolmasky, M.E. Carbapenemases: Transforming Acinetobacter baumannii into a yet more dangerous menace. Biomolecules 2020, 10, 720. [CrossRef]

93. Sully, E.K.; Geller, B.L.; Li, L.; Moody, C.M.; Bailey, S.M.; Moore, A.L.; Wong, M.; Nordmann, P.; Daly, S.M.; Sturge, C.R.; et al. Peptide-conjugated phosphorodiamidate morpholino oligomer (PPMO) restores carbapenem susceptibility to NDM-1-positive pathogensin vitroandin vivo. J. Antimicrob. Chemother. 2016, 72, 782-790. [CrossRef] [PubMed]

94. Jeon, B.; Zhang, Q. Sensitization of Campylobacter jejuni to fluoroquinolone and macrolide antibiotics by antisense inhibition of the CmeABC multidrug efflux transporter. J. Antimicrob. Chemother. 2009, 63, 946-948. [CrossRef]

95. Aunins, T.R.; E Erickson, K.; Chatterjee, A. Transcriptome-based design of antisense inhibitors potentiates carbapenem efficacy in CRE Escherichia coli. Proc. Natl. Acad. Sci. USA 2020, 117, 30699-30709. [CrossRef]

96. Eller, K.A.; Aunins, T.R.; Courtney, C.M.; Campos, J.K.; Otoupal, P.B.; Erickson, K.E.; Madinger, N.E.; Chatterjee, A. Facile accelerated specific therapeutic (FAST) platform develops antisense therapies to counter multidrug-resistant bacteria. Commun. Biol. 2021, 4, 1-13. [CrossRef]

97. Wang, X.; Wang, Y.; Ling, Z.; Zhang, C.; Fu, M.; Wang, Y.; Wang, S.; Zhang, S.; Shen, Z. Peptide nucleic acid restores colistin susceptibility through modulation of MCR-1 expression in Escherichia coli. J. Antimicrob. Chemother. 2020, 75, 2059-2065. [CrossRef]

98. Fauci, A.S. Emerging and reemerging infectious diseases: The perpetual challenge. Acad. Med. 2005, 80, 1079-1085. [CrossRef]

99. Bush, K.; Courvalin, P.; Dantas, G.; Davies, J.; Eisenstein, B.; Huovinen, P.; Jacoby, G.A.; Kishony, R.; Kreiswirth, B.N.; Kutter, E.; et al. Tackling antibiotic resistance. Nat. Rev. Genet. 2011, 9, 894-896. [CrossRef]

100. Sprenger, M.; Fukuda, K. New mechanisms, new worries. Science 2016, 351, 1263-1264. [CrossRef]

101. Teillant, A.; Gandra, S.; Barter, D.; Morgan, D.J.; Laxminarayan, R. Potential burden of antibiotic resistance on surgery and cancer chemotherapy antibiotic prophylaxis in the USA: A literature review and modelling study. Lancet Infect. Dis. 2015, 15, 1429-1437. [CrossRef]

102. Zowawi, H.M.; Harris, P.N.A.; Roberts, M.J.; Tambyah, P.A.; Schembri, M.A.; Pezzani, M.D.; Williamson, D.A.; Paterson, D.L. The emerging threat of multidrug-resistant Gram-negative bacteria in urology. Nat. Rev. Urol. 2015, 12, 570-584. [CrossRef]

103. Perez, F.; Adachi, J.; Bonomo, R.A. Antibiotic-resistant Gram-negative bacterial infections in patients with cancer. Clin. Infect. Dis. 2014, 59, S335-S339. [CrossRef]

104. Spellberg, B.; Blaser, M.; Guidos, R.J.; Boucher, H.W.; Bradley, J.S.; Eisenstein, B.I.; Gerding, D.; Lynfield, R.; Reller, L.B.; Rex, J.; et al. Combating antimicrobial resistance: Policy recommendations to save lives. Clin. Infect. Dis. 2011, 52, 397-428. [CrossRef]

105. Morens, D.M.; Fauci, A.S. Emerging infectious diseases in 2012: 20 years after the Institute of Medicine report. $m$ Bio $2012,3,3$. [CrossRef] 